\title{
Genetic diversity and morphological characteristics of native seashore paspalum in Indonesia
}

\author{
RAHAYU $^{1, \vartheta}$, FATIMAH ${ }^{2}$, EUN JI BAE ${ }^{3}$, YANG GEUN MO $^{4}$, JOON SOO CHOI ${ }^{4}$ \\ ${ }^{1}$ Department of Soil Science, Faculty of Agriculture, Universitas Sebelas Maret. Jl. Ir. Sutami 36A Surakarta 57 126, Central Java, Indonesia. \\ Tel./fax. +62-271-663375, `email: rahayu@uns.ac.id \\ ${ }^{2}$ Indonesian Center of Biotechnology and Genetic Resources, Ministry of Agriculture. J1. Tentara Pelajar 3A Bogor 16111, West Java, Indonesia \\ ${ }^{3}$ Southern Forest Resources Research Center (SFRRC). Jinju, Republic of Korea. \\ ${ }^{4}$ Bioresource Science, Dankook University. Cheonan-Si, Chungnam-Do, Republic of Korea
}

Manuscript received: 14 July 2020. Revision accepted: 2 October 2020.

\begin{abstract}
Rahayu, Fatimah, Bae EJ, Mo YG, Choi JS. 2020. Genetic diversity and morphological characteristics of native seashore paspalum in Indonesia. Biodiversitas 21: 4981-4989. Seashore paspalum (Paspalum vaginatum) is a warm-season turfgrass indigenous to tropical and coastal areas worldwide. The objectives of this study were to measure the genetic diversity and genetic variation of Indonesian seashore paspalum germplasm. Three turf quality, six morphological characters, and ten SSR (microsatellite) markers were used to assess genetic relationships and genetic variation among 22 germplasm resources from Indonesia and one commercial variety (Salam) from United States of America. The results showed significant variation for five morphological characters among 23 tested seashore paspalum accessions. The cluster analysis of morphological characters of 23 seashore paspalum accessions using 0,6 cut off divided into three morphological types: tall high-density, intermediate, and dwarf low-density ecotype. The genetic variation revealed 22 alleles with average number of alleles per locus was 2 and polymorphism information content (PIC) values average was 0.33 . The microsatellite marker cluster analysis showed that 23 seashore paspalum accessions were grouped into two major groups, with a genetic similarity coefficient was 0,72 . The low level of genetic diversity occurred among Indonesia natural grass germplasm and the gene tic distance was relatively low between Indonesian germplasm and Salam variety. The genetic diversity and morphological characteristics will be useful for further study and utilization of Indonesian seashore paspalum germplasm.
\end{abstract}

Keywords: Genetic relationship, natural grass germplasm, Paspalum vaginatum, simple sequence repeat, SSR

\section{INTRODUCTION}

In Indonesia, genus Paspalum usually used as forage for ruminant such as Paspalum dilatatum or rumput Australi and Paspalum notatum or rumput bahia (Pebriansyah et al. 2014), Paspalum conjugatum or Jampang Pahit (Stuart 2015), and Paspalum atratum or rumput swallen (Marsetyo et al. 2019) or harvested as wild cereal such as $P$. scrobiculatum or kodo millet (Hariprasanna 2017) and used as local medicinal plants such as Paspalum conjugatum or Radupu in Tane Olen, East Kalimantan (Karmilasanti and Supartini 2011) and Paspalum sp. or Jiluang Gadis in Batin, ethnic group in Jambi Province (Jalius and Muswita 2013).

Seashore paspalum (Paspalum vaginatum) is a warmseason turfgrass originating in Asia or Africa, and can be used on golf courses, athletic fields, and commercial and residential lawns. Seashore paspalum has characteristics excellent tolerance to the high salt levels, takes less fertilizer and needs less irrigation than many other turfgrasses, also tolerates a wide range in soil $\mathrm{pH}$ levels, has minimal pesticide requirements, has good insect and disease tolerance, and is fairly shade tolerant (Acuna et al. 2019). In Indonesia, seashore paspalum has been widely used as ground cover in garden, ornamental parks, golf courses, and housing. Seashore paspalum of Salam variety introduced from America is widely used in Indonesia for grass golf courses, especially near the coast and saline areas. Seashore paspalum in Banda Aceh, Nanggroe Aceh Darussalam Province known as rumput lapang was reported as common forage for Kacang goat (Iskandar and Lubis 2010). Rahayu et al. (2014) reported that seashore paspalum could grow in media using volcano eruption sand at Merapi mountain area and clayey soil.

Morphological analysis is a useful tool to study the variation and characterization of germplasm. However, environmental factors and genetic composition can both influence variance in morphological analysis (Liu et al. 2019). Compared with morphological characterization analysis, the genetic variance at the molecular level is not influenced by environmental factors. Molecular marker techniques have been applied to assess the genetic diversity of seashore Paspalum such as RAPD (Liu et al. 1994), AFLP (Chen et al. 2009), EST-SSR (Li et al. 2016), SRAP (Liu et al. 2019), SSR (Shen et al. 2020) and high-density genetic map of seashore paspalum was also available (Qi et al. 2019). The fact that SSR markers are abundant, codominant, multi-allelic, highly polymorphic, and technically efficient makes SSR preferable and attractive as genetic markers (Shultz et al. 2013). Recent years, SSR markers have been developed and applied in $P$. vaginatum (Shultz et al. 2013; Jia et al. 2015; Li et al. 2016). SSR markers have been used in genetic diversity studies of $P$. vaginatum (Liu et al. 2019, Shen et al. 2020). 
There is number of seashore paspalum germplasms distributed in Indonesia. However, there is limited information and research conducted in the characterization of these natural grass germplasm and there were no reports on genetic diversity especially seashore paspalum in Indonesia. Hence, this is the first study to investigate the genetic diversity and morphological characteristics of seashore paspalum in Indonesia. Therefore, the objectives of this study were to measure the genetic diversity and genetic variation of Indonesian seashore paspalum germplasm using turf quality, morphological characters and SSR (microsatellite) markers.

\section{MATERIALS AND METHODS}

\section{Turfgrass collection}

The survey and grass collection were conducted in mountains, highlands, karst areas, and coastal areas. Sampling site were determined based on experience in observing seashore paspalum grass in Java island surrounds the mountain areas of Merapi, Merbabu, Lawu, Sindoro, Dieng and Ungaran whereas the seaside areas were in Jepara, Bantul, Gunung Kidul, Pacitan, and Karimunjawa island while in Bali Island, the areas surveyed were Gilimanuk, Nusa Dua, Badung and Denpasar and also surveyed in Sumatra and Southeast Sulawesi. It was surveyed from March to April 2014 (Figure 1). The sampling was carried out using farming tools together with the local villagers.

The seashore paspalum was identified according to its morphological characteristics. Morphologically seashore paspalum is similar to bermudagrass (Cynodon spp.). Both species spread rapidly by stolons and rhizomes to form a fine-textured, dense turf with a deep root system. However, stolons and rhizomes of seashore paspalum are often much thicker and also darker green than those of hybrid bermudagrasses. Furthermore, seashore paspalum foliage regularly has a waxy (shiny) appearance compared to bermudagrass. This is especially pronounced on the underside (abaxial surface) of each leaf blade (Brosnan and Deputy 2008).

All of the identified seashore paspalum was recorded and photographed for the occurrence of evidence. Sampling locations were recorded as a basis for geographic distributions. The seashore paspalum samples (stolons or rhizomes) that have recorded then planted in greenhouse and maintained. The geographical position and characteristics of the ecological environment of each grass were presented in Table 1.

The vegetatively propagated seashore paspalum of twenty-two accessions collected during 2014 and cultivar "Salam" variety that widely use in Indonesia used as control were planted in April to June 2015 at experimental field of the Agriculture Faculty of University Sebelas Maret (UNS), Central Java, Indonesia (7056'07.09' S, $110^{\circ} 85^{\prime} 65.78^{\prime \prime}$ E). The research plots were arranged in a randomized complete block design with three replications. The plot size was $1.5 \mathrm{~m} \times 1.5 \mathrm{~m}$ with spaced $15 \mathrm{~cm}$ interval in the planting medium of clayey soil (Rahayu et al. 2014). It is maintained by mowing weekly or biweekly to prevent possible mixing among the accessions. Maintenance of grasses growth was applied with the irrigation of $100 \%$ evapotranspiration with 3 days interval and fertilizer NPK 4-1-2 ( $\left.15 \mathrm{~g} \mathrm{~m}^{-2}\right)$ to ensure that the turf remained healthy and developed newly expanded leaf blades.

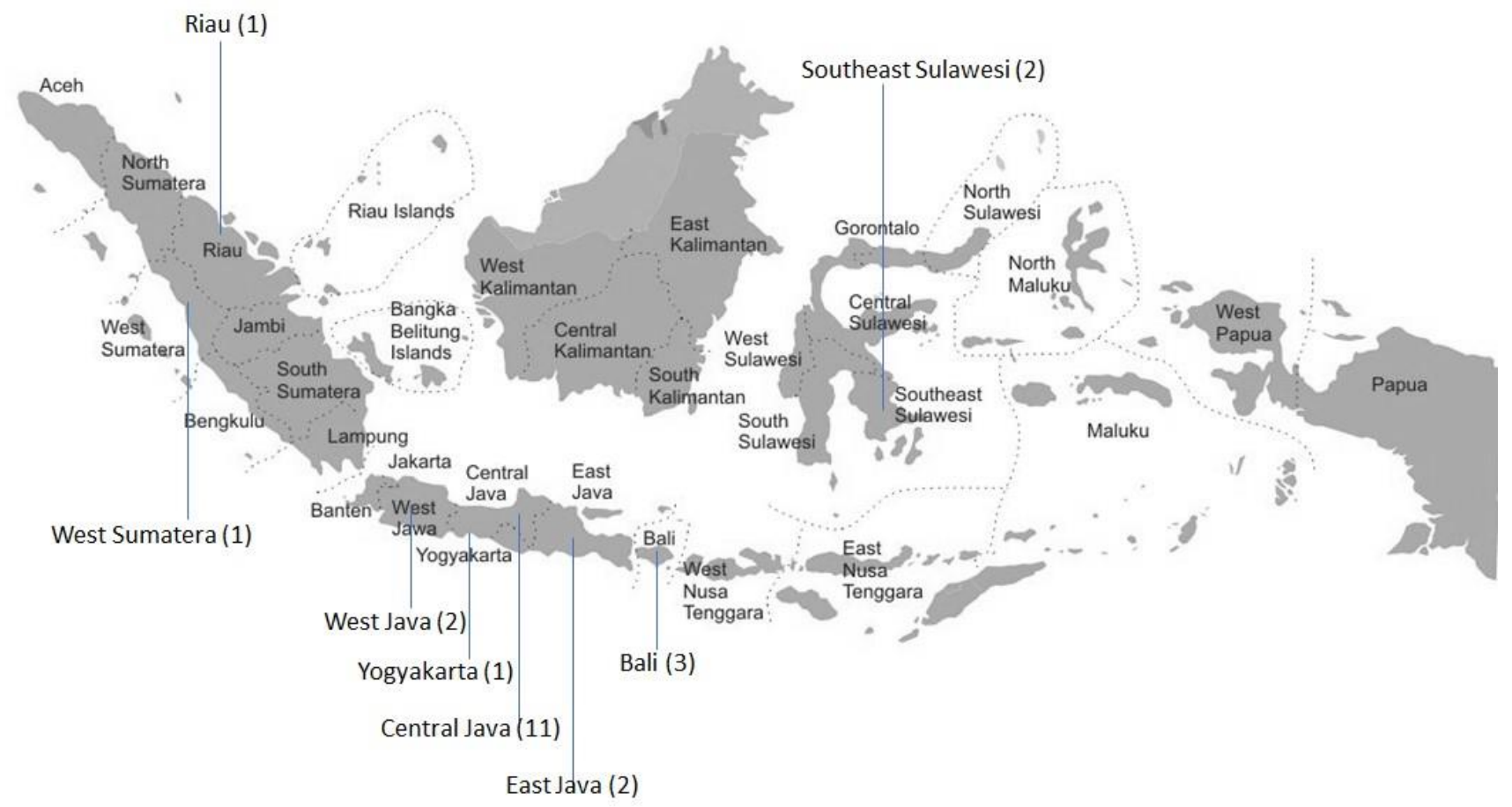

Figure 1. Map of Indonesia, showing the location of survey and sampling sites of seashore paspalum grass collected from 8 provinces. The lines indicating the province and the number of seashore paspalum sampled from each province. 
Table 1. Data of collected seashore paspalum and sampling site used in this study

\begin{tabular}{|c|c|c|c|c|c|c|}
\hline \multirow{2}{*}{ Population } & \multicolumn{6}{|c|}{ Specific sample collection site } \\
\hline & Location & Province & Site & Altitude (m) & Latitude & Longitude \\
\hline PA & Jepara & Central Java & Seaside & 3 & $6^{\circ} 33^{\prime} 55.09^{\prime \prime} \mathrm{S}$ & $110^{\circ} 39^{\prime} 35.87^{\prime \prime} \mathrm{E}$ \\
\hline PB & Kebumen & Central Java & Ground & 20 & $7^{\circ} 40^{\prime} 09.47^{\prime \prime} \mathrm{S}$ & $109^{\circ} 30^{\prime} 05.05 ” \mathrm{E}$ \\
\hline $\mathrm{PC}$ & Tanah Lot & Bali & Beach & 4 & $8^{\circ} 37^{\prime} 16.37^{\prime \prime} \mathrm{S}$ & $115^{\circ} 05^{\prime} 12.51^{\prime \prime} \mathrm{E}$ \\
\hline PD & Rumbai & West Sumatra & Roadside & 5 & $0^{\circ} 33^{\prime} 8.23 ” \mathrm{~S}$ & $101^{\circ} 26^{\prime} 2.78^{\prime \prime} \mathrm{E}$ \\
\hline $\mathrm{PE}$ & Siak & Riau & Roadside & 11 & $0^{\circ} 54^{\prime} 25.84^{\prime \prime} \mathrm{S}$ & $102^{\circ} 09^{\prime} 06.89^{\prime \prime} \mathrm{E}$ \\
\hline $\mathrm{PF}$ & Bogor & West Java & Golf course & 254 & $6^{\circ} 35^{\prime} 52.85^{\prime \prime} \mathrm{S}$ & $106^{\circ} 50^{\prime} 18.48^{\prime \prime} \mathrm{E}$ \\
\hline PG & Jepara 2 & Central Java & Seaside & 3 & $6^{\circ} 33^{\prime} 55.09 ” \mathrm{~S}$ & $110^{\circ} 39^{\prime} 35.87^{\prime \prime} \mathrm{E}$ \\
\hline PH & Ponorogo & East Java & Lawn & 98 & $7^{\circ} 54^{\prime} 20.13 ” \mathrm{~S}$ & $111^{\circ} 27^{\prime} 27.57^{\prime \prime} \mathrm{E}$ \\
\hline PI & Magelang & Central Java & Golf course & 390 & $7^{\circ} 29^{\prime} 36.67^{\prime \prime} \mathrm{S}$ & $110^{\circ} 12^{\prime} 48.08^{\prime \prime} \mathrm{E}$ \\
\hline PJ & Salam & Control variety & UNS field & 155 & $7^{\circ} 56^{\prime} \quad 07.09 ” \mathrm{~S}$ & $110^{\circ} 85^{\prime} 65.78^{\prime \prime} \mathrm{E}$ \\
\hline PK & Temanggung & Central Java & Arable land & 1150 & $7^{\circ} 15^{\prime} 01.52 ” \mathrm{~S}$ & $110^{\circ} 01^{\prime} 42.12^{\prime \prime} \mathrm{E}$ \\
\hline PL & Klaten & Central Java & Lawn & 350 & $7^{\circ} 42^{\prime} 20.99^{\prime \prime} \mathrm{S}$ & $110^{\circ} 36^{\prime} 23^{\prime \prime} \mathrm{E}$ \\
\hline PM & Kendari & Southeast Sulawesi & Roadside & 18 & $4^{\circ} 01$ ' $06.60^{\prime \prime} \mathrm{S}$ & $122^{\circ} 30^{\prime} 52.633^{\prime \prime} \mathrm{E}$ \\
\hline $\mathrm{PN}$ & Wakatobi & Southeast Sulawesi & Seaside & 5 & $5^{\circ} 32,49.56 ” \mathrm{~S}$ & $123^{\circ} 48^{\prime} 06.41^{\prime \prime} \mathrm{E}$ \\
\hline PO & Jepara Kartini & Central Java & Seaside & 4 & $6^{\circ} 35^{\prime} 24.24 ” \mathrm{~S}$ & $110^{\circ} 38^{\prime} 52.46^{\prime \prime} \mathrm{E}$ \\
\hline PP & Jembrana & Bali & Seaside & 3 & $8^{\circ} 21^{\prime} 00.41 ” \mathrm{~S}$ & $114^{\circ} 32^{\prime} 52.03^{\prime \prime} \mathrm{E}$ \\
\hline PQ & Mojogedang & Central Java & Roadside & 400 & $7^{\circ} 32^{\prime} 58.992^{\prime \prime} \mathrm{S}$ & $110^{\circ} 59^{\prime} 11.144 " \mathrm{E}$ \\
\hline PR & Bogor 2 & West Java & Golf Course & 250 & $6^{\circ} 35^{\prime} 52.85^{\prime \prime} \mathrm{S}$ & $106^{\circ} 50 ’ 18.48 " \mathrm{E}$ \\
\hline PS & Karanganyar & Central Java & Ground & 350 & $7^{\circ} 36^{\prime} 25.463 " \mathrm{~S}$ & $110^{\circ} 59^{\prime} 12.098^{\prime \prime} \mathrm{E}$ \\
\hline PT & Tasikmadu & Central Java & Roadside & 340 & $7^{\circ} 34^{\prime} 28.29 " \mathrm{~S}$ & $110^{\circ} 55^{\prime} 4.735^{\prime \prime} \mathrm{E}$ \\
\hline PU & Jembrana 2 & Bali & Seaside & 3 & $8^{\circ} 21^{\prime} 00.41^{\prime \prime} \mathrm{S}$ & $114^{\circ} 32^{\prime} 52.03^{\prime \prime} \mathrm{E}$ \\
\hline PV & Parangtritis & Yogyakarta & Roadside & 10 & $7^{\circ} 58,33.94 ” \mathrm{~S}$ & $110^{\circ} 19^{\prime} 00.30^{\prime \prime} \mathrm{E}$ \\
\hline PW & Ngawi & East Java & Lawn & 74 & $7^{\circ} 22^{\prime} 15.28^{\prime \prime} \mathrm{S}$ & $111^{\circ} 10^{\prime} 22.49 " \mathrm{E}$ \\
\hline
\end{tabular}

\section{Morphological characterization of seashore paspalum}

The morphological characterization of seashore paspalum was measured using seven vegetative (turf quality and turf quantity character) on forty days after seedling (DAS) and two reproductive characters (spikelet length and grain per spikelet) on sixty DAS. The turf quality character of the grass covering the visual quality of texture, uniformity, shoot density, and growth rate, also level of surface coverage was observed within the plot. The turf quality and shoot density were evaluated following visual field assessment (VFA) of The National Turfgrass Evaluation Program (NTEP) method (NTEP 2008) with scale of 1-9 $(1.0=$ poorest possible quality and $9.0=$ best possible quality) where the " 6 " score as the minimally acceptable value for the assessment. The turf quantity character such as plant height, leaf length, leaf width and internode length were measured with calipers ruler.

\section{Molecular analysis}

Genomic DNA was extracted from fresh leaves of each accession using DNA isolation method (Dellaporta 1983). Extraction buffer was added to crushed leaves tissues (sodium bisulfite was added shortly before use). Tube is shaken well and then heated in a water bath temperature of $65{ }^{\circ} \mathrm{C}$ for $15-30$ minutes. A cold solution of chloroform: isoamyl alcohol $(24: 1, \mathrm{v} / \mathrm{v})$ was added to buffer with a ratio $(1: 1, \mathrm{v} / \mathrm{v})$ and shake for $10-15$ minutes. Tubes centrifuged at a speed of $12,000 \mathrm{rpm}$ for 15 minutes. Supernatant was transferred into a new tube. As much as $2 / 3$ volume of cold isopropanol was added to the supernatant and then the tube is shaken gently. If necessary, $3 \mathrm{M}$ ammonium acetate can be added as much as 1/10 volume and the pellet resulted from centrifugation for 12 minutes was rinsed with cold
$70 \%$ ethanol and then dried for 15-30 minutes. Stock DNA was dissolved in $50 \mu \mathrm{L}$ of TE buffer ( $\mathrm{pH}$ 8.0). The DNA was qualified in $0,8 \%$ agarose gel and quantified using nanodrop.

Molecular analysis was performed using 10 microsatellite primers in Table 2 developed from Paspalum genome (Shultz et al. 2013). PCR reactions containing 100 $\mathrm{ng}$ of genomic DNA, $10 \mathrm{pmol}$ of each primer, $1.5 \mathrm{mM}$ $\mathrm{MgCl}_{2}, 0.2 \mathrm{mM}$ of each dNTP, and 0.2 units of Taq DNA polymerase (Dream Taq, Thermo Fisher Scientific US). The PCR condition was initial denaturation at $94{ }^{\circ} \mathrm{C}$ for 5 minutes followed by denaturation at $94{ }^{\circ} \mathrm{C}$ for $1 \mathrm{~min}$, annealing at a temperature of $55^{\circ} \mathrm{C}$ for 1 minute and $72{ }^{\circ} \mathrm{C}$ for 1 minute for 35 cycles followed and a final extension for $7 \mathrm{~min}$ at $72{ }^{\circ} \mathrm{C}$. The PCR products were electroporated on $8 \%$ acrylamide gel or $2 \%$ agarose gel, followed by ethidium bromide staining. Then gel electrophoresis was visualized and documented using gel documentation (Biorad).

\section{Data analysis}

Data analysis of morphological characteristics was performed using Ms Excell and SPSS program to analyze the variation (ANOVA) of the morphological data. Duncan significant difference (DMRT) was determined at a five percent probability level to make the comparison between the mean values of each accession. The amplified bands of the PCR products were scored using PhotoCapMW. The molecular data were analyzed using Power marker to generate Polymorphism Information Content (PIC) and GeneAlex for AMOVA analysis. Cluster analysis was constructed using NTSYS ver.2.0 with SAHN and UPGMA trees. 
Table 2. Primer list used in this study (Shultz et al. 2013)

\begin{tabular}{|c|c|c|c|c|c|}
\hline Primer & Forward Sequence & Reverse Sequence & Repeat & Size (bp) & Chr \\
\hline $\operatorname{ctg} 02617$ & TATTTTGTGACATCGTCGGTGAGT & CTACTTGCTGTGACGGAAAGGATT & (CT)7 & $165-179$ & 3 \\
\hline $\operatorname{ctg} 02478$ & CAGGTTGCCTCACTCAGAAGAACT & TGTGTTTTCTTGGTCTTGGTCAGA & (TC) 16 & $135-162$ & 5 \\
\hline $\operatorname{ctg} 01792$ & CTTTGGTAGCCATTGTGTTTACCC & TCCAGATGCCTTTAGTAGTTTGGC & (TTAT) 4 & $170-185$ & - \\
\hline $\operatorname{ctg} 00695$ & TAGAATCCCAGAAACTCTGCAAGC & GTCGTCTCGCTAAACAATAAGCGT & (AGA)4 & $150-178$ & 4 \\
\hline $\operatorname{ctg} 05574$ & GATATCTGAAGCAGAATGCCCACT & AGAGGAGCTCTCGAAAAAGGTACG & (CGC)4 & $155-163$ & - \\
\hline $\operatorname{ctg} 13333$ & CTCTTCGCCAAGTACAAGATCCAG & TCTAGTATTCTGGATGGACGGACAA & $(\mathrm{CTT}) 4$ & $105-130$ & 4 \\
\hline $\operatorname{ctg} 598$ & CACAGACAAAGCACTGGATCTCAT & GATGCAGGGTGGAAATAAGAAGAA & $(\mathrm{CTT}) 4$ & $116-150$ & 3 \\
\hline $\operatorname{ctg} 02718$ & TGACAATGACTATGGTGGATACGG & AGACCAATACCATCCTCСТCCTTC & (GAG)3 & $77-180$ & 4 \\
\hline $\operatorname{ctg} 02534$ & GAGACGTTCGACAGGAACGC & ATGGCCAATTTGCTCATCCC & $(\mathrm{GAT}) 4$ & $140-206$ & 6 \\
\hline $\operatorname{ctg} 00721$ & AGGGGTATAAGAAGAAGCCTGCTG & CTCGTACTTTCCTCCTCCATAGCC & (GTG)4 & $125-130$ & 1 \\
\hline
\end{tabular}

\section{RESULTS AND DISCUSSION}

\section{Morphological characterization of seashore paspalum}

The morphological characteristics as standard parameters were used in this study to determine the performance of the seashore paspalum. The collected data can provide a preliminary evaluation of the accessions. The comparison of a number of Indonesian seashore paspalum accessions with commercial cultivar Salam variety provides a first screening of new plant material.

The coefficients variation (CV) observed of turfgrass quality, shoot density, and surface coverage were high $(>50 \%$ ) with the maximum $\mathrm{CV}$ value was surface coverage character $(64,14 \%)$ while the $\mathrm{CV}$ of turfgrass quantity character leaf length, leaf width, internode length, spikelet length, grain per spikelet were less than $23 \%$ with the minimum was grain per spikelet $(10,99 \%)$ (Table 3$)$. The results indicated rich variation among 23 seashore paspalum accessions in turf quality but slightly different compare to turf morphological character (Figure 2).

The shoot density and turf quality rated with acceptable value (score > 6) observed in 17 accessions, within this the highest quality was "Salam" variety (score 8,5 and 9) while the low quality (score <6) observed in five accessions (PG, PM, PN, PP, and PU). High surface coverage rate (>90\%) was found in 11 accessions (PB, PD, PM, PR, PS, PH, PI, $\mathrm{PK}, \mathrm{PL}, \mathrm{PQ}$, and PT) while very low rate of surface coverage was found in two accessions PC and PO (5\%) and Salam variety were also low $(10 \%)$ (Table 3$)$. In the turf quality characterization, $\mathrm{PH}$ from Ponorogo and $\mathrm{PB}$ from Kebumen was high in turf quality (score 8), shoot density (score 8), and surface coverage (90\%) (Table 3).

The morphological characteristic of local seashore paspalum in vegetative phase was compared to Salam variety as the threshold. The plant height character separated into short/dwarf $(<10 \mathrm{~cm})$ consisted of 4 accessions (PC, PF, PR, PU, and Salam variety) and tall $(>10 \mathrm{~cm})$ consisted of 18 accessions. The leaf width character separated into fine leaves $(<3 \mathrm{~mm})$ consisted of 11 accessions (PA, PC, PD, PE, PF, PK, PM, PN, PS, PU, $\mathrm{PV}$, and Salam) and wider leaves $(>4 \mathrm{~mm})$ consisted of 11 accessions (PB, PG, PH, PI, PL, PO, PP, PQ, PR, PT, PW). The leaf length character separated into short leaves $(<3,5$ $\mathrm{cm}$ ) consisted of 5 accessions (PC, PF, PK, PU, PV, and
Salam) and long leaves (> $3.5 \mathrm{~cm}$ ) consisted of 17 accessions (PA, PB, PP, PE, PG, PH, PI, PL, PM, PN, PO, PP, PQ, PR, PS, PT, PW) (Table 3).

The morphological characteristic of local seashore paspalum in generative phase was compared to Salam variety as the threshold. The internode length character separated into short internode/dwarf $(<2.17 \mathrm{~cm})$ consisted of 8 accessions (PC, PD, PE, PK, PP, PT, PU, PV, and Salam) and long internode $(>2,1 \mathrm{~cm})$ consisted of 14 accessions (PA, PB, PF, PG, PH, PI, PL, PM, PN, PO, PQ, $\mathrm{PR}, \mathrm{PS}, \mathrm{PW})$. The spikelet length and grain per spikelet characters observed fewer seed and short spikelet in 13 accessions (PA, PC, PD, PF, PM, PN, PO, PP, PR, PS, PU, $\mathrm{PW}, \mathrm{PH}$, and Salam) and more seeds and longer spikelet in 9 accessions (PB, PE, PG, PI, PK, PL, PQ, PT, PV) (Table $3)$. Based on morphological characteristic in vegetative (plant height, leaf length, and leaf width) and generative phase (internode length, spikelet length, and grain per spikelet) revealed that PC (Tanah Lot, Bali) and PU (Jembrana, Bali) were similar to commercial "Salam" variety or dwarf low-density ecotype.

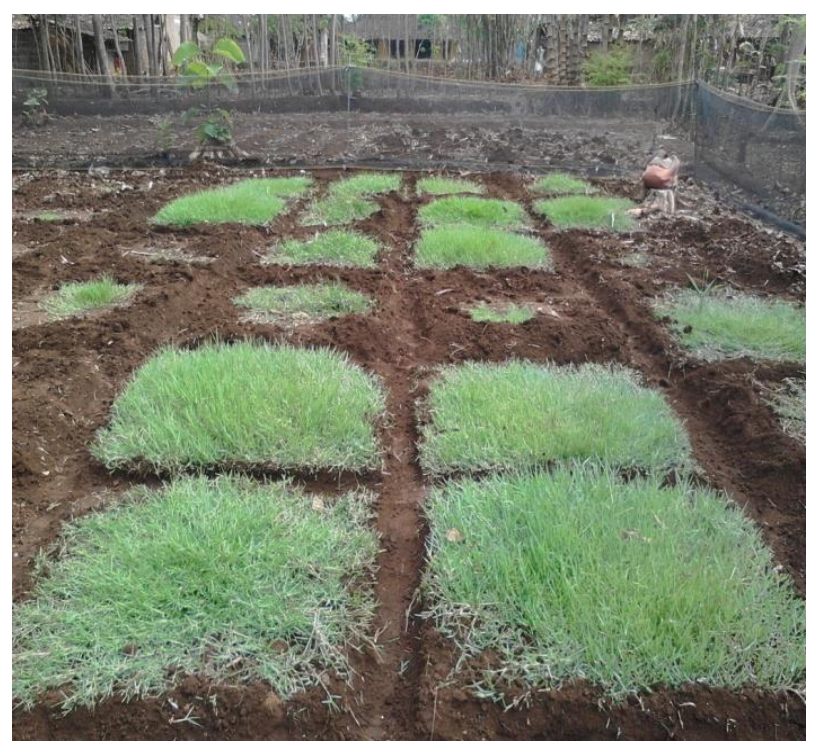

Figure 2. The natural grass of seashore paspalum from collected germplasm 40 days after seedling (DAS) that have formed dense colonies for the evaluation of quality, leaf color, and morphological characteristic 
Table 3. Morphological characteristic of 23 seashore paspalum accessions analyzed in this study

\begin{tabular}{|c|c|c|c|c|c|c|c|c|c|}
\hline Population & $\begin{array}{c}\text { Shoot } \\
\text { density } \\
\text { (score) }\end{array}$ & $\begin{array}{c}\text { Turf } \\
\text { quality } \\
\text { (score) }\end{array}$ & $\begin{array}{c}\text { Surface } \\
\text { coverage } \\
(\%)\end{array}$ & $\begin{array}{c}\text { Turf } \\
\text { height } \\
\text { (cm) }\end{array}$ & $\begin{array}{l}\text { Leaf length } \\
(\mathrm{cm})\end{array}$ & $\begin{array}{c}\text { Leaf width } \\
(\mathrm{cm})\end{array}$ & $\begin{array}{l}\text { Internode } \\
\text { length }(\mathrm{cm})\end{array}$ & $\begin{array}{c}\text { Spikelet } \\
\text { length }(\mathbf{c m})\end{array}$ & $\begin{array}{l}\text { Grain per } \\
\text { spikelet }\end{array}$ \\
\hline PA & 7 & 6 & 30 & 20 & $8.7 \pm 1.53^{\mathrm{ef}}$ & $0.3 \pm 0.03^{\mathrm{a}-\mathrm{c}}$ & $2.3 \pm 0.46^{\mathrm{c}-\mathrm{h}}$ & $0.0 \pm 0.00^{\mathrm{a}}$ & $0.0 \pm 0.00^{\mathrm{a}}$ \\
\hline PB & 8 & 7 & 90 & 24 & $4.8 \pm 0.76^{\mathrm{b}-\mathrm{d}}$ & $0.5 \pm 0.03^{\mathrm{de}}$ & $2.3 \pm 0.66^{\mathrm{c}-\mathrm{g}}$ & $2.7 \pm 0.29^{\mathrm{d}}$ & $14.0 \pm 1.00^{\mathrm{c}}$ \\
\hline $\mathrm{PC}$ & 7 & 5 & 5 & 8 & $3.5 \pm 0.50^{\mathrm{a}-\mathrm{c}}$ & $0.3 \pm 0.00^{\mathrm{a}-\mathrm{c}}$ & $1.6 \pm 0.49^{\mathrm{a}-\mathrm{d}}$ & $0.0 \pm 0.00^{\mathrm{a}}$ & $0.0 \pm 0.00^{\mathrm{a}}$ \\
\hline PD & 7 & 7.5 & 90 & 17 & $5.8 \pm 0.64^{\mathrm{d}}$ & $0.3 \pm 0.10^{\mathrm{a}-\mathrm{c}}$ & $1.7 \pm 0.35^{\mathrm{a}-\mathrm{d}}$ & $0.0 \pm 0.00^{\mathrm{a}}$ & $0.0 \pm 0.00^{\mathrm{a}}$ \\
\hline PE & 6.5 & 7 & 40 & 10 & $5.7 \pm 1.16^{\mathrm{cd}}$ & $0.3 \pm 0.10^{\mathrm{a}-\mathrm{c}}$ & $1.9 \pm 0.27^{\mathrm{a}-\mathrm{f}}$ & $0.9 \pm 0.79^{\mathrm{b}}$ & $8.3 \pm 7.23^{\mathrm{b}}$ \\
\hline $\mathrm{PF}$ & 7 & 6.5 & 20 & 6 & $3.3 \pm 0.76^{\mathrm{ab}}$ & $0.3 \pm 0.06^{\mathrm{ab}}$ & $2.1 \pm 0.79^{\mathrm{c}-\mathrm{g}}$ & $0.0 \pm 0.00^{\mathrm{a}}$ & $0.0 \pm 0.00^{\mathrm{a}}$ \\
\hline PG & 4 & 4 & 50 & 21 & $5.0 \pm 1.00^{\mathrm{b}-\mathrm{d}}$ & $0.4 \pm 0.10^{\mathrm{b}-\mathrm{d}}$ & $2.1 \pm 0.66^{\mathrm{c}-\mathrm{g}}$ & $1.7 \pm 0.29^{c}$ & $14.7 \pm 2.52^{c}$ \\
\hline $\mathrm{PH}$ & 8 & 7.5 & 95 & 15 & $5.5 \pm 0.50^{\mathrm{b}-\mathrm{d}}$ & $0.4 \pm 0.10^{\mathrm{b}-\mathrm{d}}$ & $2.6 \pm 0.17^{\mathrm{e}-\mathrm{h}}$ & $0.0 \pm 0.00^{\mathrm{a}}$ & $0.0 \pm 0.00^{\mathrm{a}}$ \\
\hline PI & 6 & 6 & 95 & 22 & $6.2 \pm 0.76^{\mathrm{d}}$ & $0.5 \pm 0.00^{\mathrm{de}}$ & $2.8 \pm 0.25^{\mathrm{f}-\mathrm{i}}$ & $2.7 \pm 0.29^{d}$ & $15.7 \pm 1.16^{\mathrm{c}}$ \\
\hline PK & 7.5 & 7.5 & 95 & 11 & $2.4 \pm 0.51^{\mathrm{a}}$ & $0.3 \pm 0.00^{\mathrm{a}-\mathrm{c}}$ & $1.9 \pm 0.21^{\mathrm{b}-\mathrm{f}}$ & $2.4 \pm 0.36^{\mathrm{d}}$ & $14.7 \pm 1.53^{\mathrm{c}}$ \\
\hline PL & 6.5 & 6.5 & 98 & 22 & $5.5 \pm 0.50^{b-d}$ & $0.4 \pm 0.10^{\mathrm{b}-\mathrm{d}}$ & $2.7 \pm 0.36^{\mathrm{e}-\mathrm{h}}$ & $2.3 \pm 0.36^{\mathrm{d}}$ & $13.3 \pm 2.08^{\mathrm{c}}$ \\
\hline PM & 4.5 & 5 & 90 & 20 & $6.7 \pm 0.58^{\mathrm{de}}$ & $0.3 \pm 0.06^{\mathrm{ab}}$ & $3.3 \pm 0.40^{\mathrm{hi}}$ & $0.0 \pm 0.00^{\mathrm{a}}$ & $0.0 \pm 0.00^{\mathrm{a}}$ \\
\hline $\mathrm{PN}$ & 4.5 & 4.5 & 70 & 33 & $8.5 \pm 1.32^{\mathrm{ef}}$ & $0.3 \pm 0.06^{\mathrm{ab}}$ & $3.6 \pm 0.36^{\mathrm{i}}$ & $0.0 \pm 0.00^{\mathrm{a}}$ & $0.0 \pm 0.00^{\mathrm{a}}$ \\
\hline $\mathrm{PO}$ & 5.5 & 6 & 6.5 & 19 & $9.3 \pm 3.22^{\mathrm{f}}$ & $0.4 \pm 0.06^{\mathrm{b}-\mathrm{d}}$ & $2.8 \pm 0.75^{\mathrm{f}-\mathrm{i}}$ & $0.0 \pm 0.00^{\mathrm{a}}$ & $0.0 \pm 0.00^{\mathrm{a}}$ \\
\hline PP & 5 & 5 & 25 & 16 & $4.8 \pm 0.76^{\mathrm{b}-\mathrm{d}}$ & $0.4 \pm 0.06^{\mathrm{b}-\mathrm{d}}$ & $1.9 \pm 0.40^{\mathrm{a}-\mathrm{e}}$ & $0.0 \pm 0.00^{\mathrm{a}}$ & $0.0 \pm 0.00^{\mathrm{a}}$ \\
\hline PQ & 5 & 6 & 100 & 18 & $5.0 \pm 1.00^{\mathrm{b}-\mathrm{d}}$ & $0.5 \pm 0.00^{\mathrm{de}}$ & $2.8 \pm 0.25^{\mathrm{f}-\mathrm{i}}$ & $1.7 \pm 0.29^{c}$ & $12.3 \pm 2.31^{\mathrm{c}}$ \\
\hline PR & 7.5 & 7.5 & 90 & 8 & $5.0 \pm 1.00^{\mathrm{b}-\mathrm{d}}$ & $0.4 \pm 0.06^{\mathrm{b}-\mathrm{d}}$ & $2.0 \pm 0.20^{\mathrm{c}-\mathrm{f}}$ & $0.0 \pm 0.00^{\mathrm{a}}$ & $0.0 \pm 0.00^{\mathrm{a}}$ \\
\hline PS & 7 & 7 & 90 & 13 & $5.0 \pm 1.00^{\mathrm{b}-\mathrm{d}}$ & $0.3 \pm 0.00^{\mathrm{a}-\mathrm{c}}$ & $2.9 \pm 0.90^{\mathrm{g}-\mathrm{i}}$ & $0.0 \pm 0.00^{\mathrm{a}}$ & $0.0 \pm 0.00^{\mathrm{a}}$ \\
\hline PT & 6 & 6 & 100 & 25 & $6.0 \pm 1.00^{\mathrm{d}}$ & $0.6 \pm 0.15^{\mathrm{e}}$ & $1.5 \pm 0.25^{\mathrm{a}-\mathrm{c}}$ & $1.8 \pm 0.29^{c}$ & $13.7 \pm 2.31^{\mathrm{c}}$ \\
\hline PU & 5 & 5 & 10 & 4 & $2.5 \pm 0.50^{\mathrm{a}}$ & $0.2 \pm 0.03^{\mathrm{a}}$ & $1.1 \pm 0.15^{\mathrm{a}}$ & $0.0 \pm 0.00^{\mathrm{a}}$ & $0.0 \pm 0.00^{\mathrm{a}}$ \\
\hline PV & 7 & 6.5 & 20 & 12 & $3.3 \pm 0.29^{\mathrm{ab}}$ & $0.3 \pm 0.06^{\mathrm{ab}}$ & $2.2 \pm 0.29^{c-g}$ & $1.5 \pm 0.00^{c}$ & $13.0 \pm 0.00^{c}$ \\
\hline PW & 7 & 7 & 10 & 22 & $6.7 \pm 2.08^{\mathrm{de}}$ & $0.4 \pm 0.15^{\mathrm{c}-\mathrm{e}}$ & $2.4 \pm 0.40^{\mathrm{d}-\mathrm{h}}$ & $0.0 \pm 0.00^{\mathrm{a}}$ & $0.0 \pm 0.00^{\mathrm{a}}$ \\
\hline PJ (Salam) & 8.5 & 9 & 10 & 2 & $1.7 \pm 0.25^{\mathrm{a}}$ & $0.2 \pm 0.10^{\mathrm{a}}$ & $1.1 \pm 0.15^{\mathrm{ab}}$ & $0.0 \pm 0.00^{\mathrm{a}}$ & $0.0 \pm 0.00^{\mathrm{a}}$ \\
\hline Mean & 6.4 & 6.07 & 60.14 & 16.19 & 5.26 & 0.35 & 2.23 & 0.78 & 5.38 \\
\hline Minimum & 4 & 4 & 5 & 2 & 1.73 & 0.18 & 1.1 & 0 & 0 \\
\hline Maximum & 8.5 & 9 & 98 & 33 & 9.33 & 0.56 & 3.6 & 2.67 & 15.67 \\
\hline SD & 3.26 & 3.11 & 38.57 & 8.7 & 0.94 & 0.06 & 0.53 & 0.1 & 0.59 \\
\hline $\mathrm{CV}(\%)$ & 50.88 & 51.28 & 64.14 & 53.75 & 17.86 & 17.34 & 23.8 & 13.17 & 10.99 \\
\hline
\end{tabular}

Note: Means followed by the same letter in a column are not significantly difference at $P \leq 0.05 . \mathrm{SD}=\mathrm{Standard}$ deviation, $\mathrm{CV}(\%)=$ Coefficient of variance and Fprob= F probability, * means significantly difference at $P \leq 0.05$, "_." not counted.

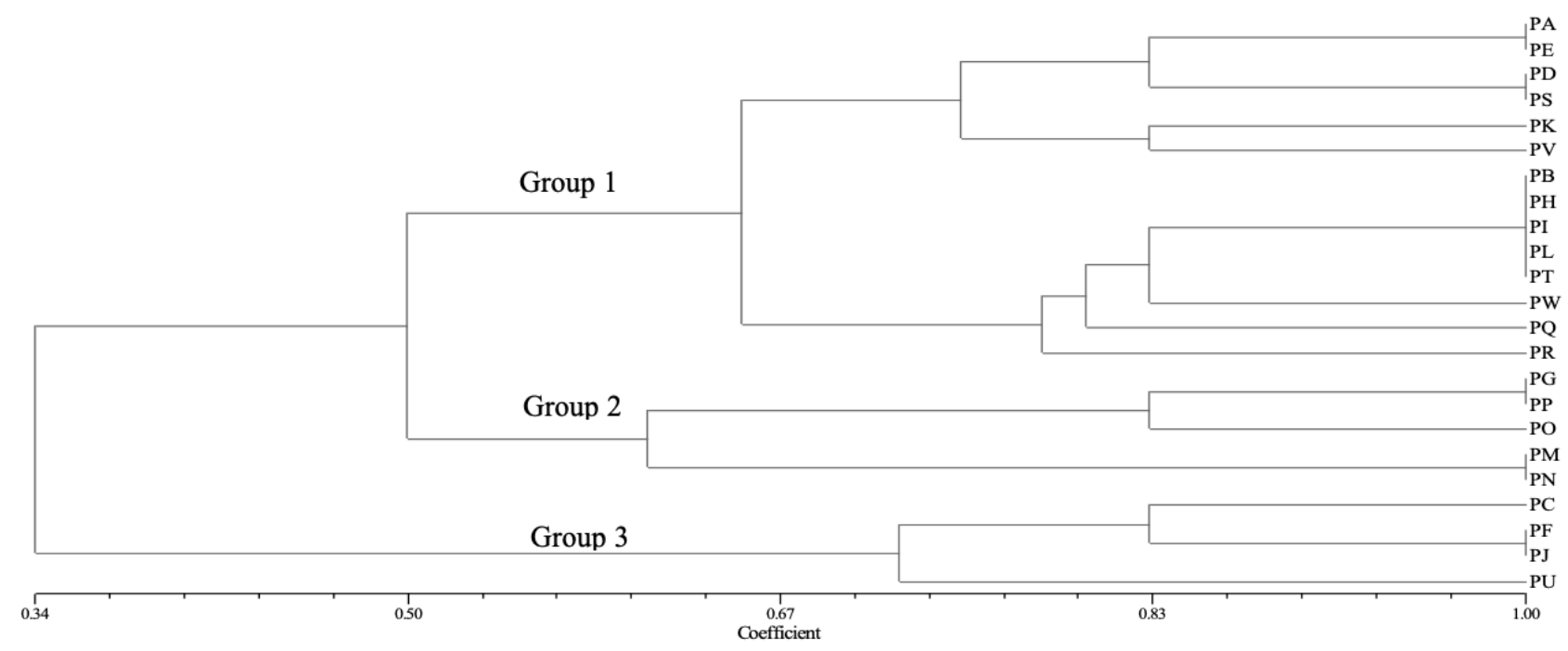

Figure 3. UPGMA dendrogram of seashore paspalum showing the genetic relationships between 23 seashore paspalum accessions based on turfgrass quality and morphological characterization revealed three major groups 
A dendrogram was constructed from turfgrass quality and morphological characterization. When a cutoff value of 0.60 was used for genetic similarity among all accessions as the threshold for UPGMA clustering three major groups were observed. Group 1 consisted of 14 accessions (PA, PE, PD, PS, PK, PV, PB, PH, PI, PL, PT, PW, PQ, and $\mathrm{PR}$ ). Group 2 consisted of 5 accessions (PG, PP, PO, PM, and PN). Group 3 consisted of 3 accessions (PC, PF, and PU) clustered with widely used seashore paspalum "Salam" variety (Figure 3).

\section{Polymorphism analysis and genetic variation of seashore paspalum}

Nine out of ten SSRs used for genotyping showed good polymorphism and were able to be measured in 19 Indonesian seashore paspalum germplasms (Figure 4). The genetic variation revealed 22 number of alleles with the average number of alleles per locus was 2 ranged from 2 (ctg598, ctg00721, ctg01792, $\operatorname{ctg} 02478, \quad \operatorname{ctg} 02534$, ctg02617, $\operatorname{ctg} 05574)$ to 4 ( $\operatorname{ctg} 02718)$. Gene diversity or expected heterozygosity $\left(\mathrm{H}_{\mathrm{e}}\right)$ is the probability that two alleles are randomly selected from a population (Babu et al. 2017). Gene diversity value ranged from a low of 0,145 (ctg598) to a high of 0,66 (ctg00695 and $\operatorname{ctg} 02718)$ with an average of 0,439 and heterozygosity $\left(\mathrm{H}_{\mathrm{o}}\right)$ value ranged from a low of $0,00(\operatorname{ctg} 02718)$ to a high of $0,78(\operatorname{ctg} 02478)$ with the average of 0,442 . PIC values provide information about the polymorphism of a marker. The PIC values average was 0.36 and ranged from a low of 0.13 (ctg598) to a high of 0.61 (ctg02718) (Table 4). The presence of 22 alleles in the 23 accessions indicates low genetic diversity and low in PIC value within the microsatellite markers.

An AMOVA study of Indonesian seashore paspalum was performed to analyze the distribution of genetic diversity between and within the populations. AMOVA analyses showed that $83 \%$ variance exists within individuals whereas $12 \%$ variance was present among populations (Table 5). The 23 of Indonesian seashore paspalum with 9 microsatellite primers yielded $59.26 \%$ in average of polymorphic bands. Central Java has the highest diversity with maximum $\mathrm{P}, \mathrm{Ne}$, and $\mathrm{H}$ values while Southeast Sulawesi has the smallest value for $\mathrm{P}, \mathrm{Ne}$, and He which infers a relatively low genetic variation (Table $6)$.

Cluster analysis was performed on similarity coefficient matrices calculated from molecular markers to generate a dendrogram. When a cutoff value of 0.70 was used for genetic similarity among all varieties as the threshold for UPGMA clustering two major groups were observed. Group 1 consisted of 5 accessions i.e: PA, PN, PM, PP, and PU clustered with widely used seashore paspalum "Salam" variety. This group consisted of seashore paspalum originated from Central Java (PA), South Sulawesi (PM and PN), and Bali (PP and PU). Group 2 consists of 13 accessions i.e: PB, PC, PE, PF, PD, PO, PG, PI, PT, PR, $\mathrm{PS}, \mathrm{PL}$, and PQ. In this group consisted of seashore paspalum originated from Bali (PB), Riau, (PE), West Sumatra (PD, West Java (PF and PR), and Central Java (PB, PO, PG, PI, PT, PS, PL, and PQ) (Figure 5).

Table 4. Summary statistic of microsatellite primers used in this study

\begin{tabular}{lcccc}
\hline Primer & $\begin{array}{c}\text { Allele } \\
\text { number } \\
(\mathbf{N a})\end{array}$ & $\begin{array}{c}\text { Gene } \\
\text { diversity } \\
\left(\mathbf{H}_{\mathbf{e}}\right)\end{array}$ & $\begin{array}{c}\text { Heterozygosity } \\
\left.\mathbf{( H}_{\mathbf{o}}\right)\end{array}$ & PIC \\
\hline ctg598 & 2 & 0.145 & 0.158 & 0.135 \\
$\operatorname{ctg} 00695$ & 3 & 0.666 & 0.684 & 0.592 \\
$\operatorname{ctg} 00721$ & 2 & 0.488 & 0.316 & 0.369 \\
$\operatorname{ctg} 01792$ & 2 & 0.453 & 0.538 & 0.350 \\
$\operatorname{ctg} 02478$ & 2 & 0.494 & 0.789 & 0.372 \\
$\operatorname{ctg} 02534$ & 2 & 0.450 & 0.684 & 0.349 \\
$\operatorname{ctg} 02718$ & 4 & 0.660 & 0,000 & 0.610 \\
$\operatorname{ctg} 02617$ & 2 & 0.161 & 0.176 & 0.148 \\
$\operatorname{ctg} 05574$ & 2 & 0.432 & 0.632 & 0.339 \\
Mean & 2,333 & 0.439 & 0.442 & 0.363 \\
\hline
\end{tabular}

Note: $\mathrm{H}_{\mathrm{e}}$ : Expected heterozygosity, $\mathrm{H}_{\mathrm{o}}$ : Observed heterozygosity, PIC: Polymorphism Information Content

Table 5. Summary of Analysis of Molecular Variance (AMOVA) of Indonesian seashore paspalum

\begin{tabular}{lccccc}
\hline \multicolumn{1}{c}{ Source } & df & SS & MS & Est. Var. & \% \\
\hline Among populations & 4 & 15.449 & 3.862 & 0.274 & $12 \%$ \\
Among individuals & 14 & 29.867 & 2.133 & 0.106 & $5 \%$ \\
Within individuals & 19 & 36.500 & 1.921 & 1.921 & $83 \%$ \\
Total & 37 & 81.816 & & 2.301 & $100 \%$ \\
Fst & 0.119 & & & & \\
Nm & 1.851 & & & & \\
\hline
\end{tabular}

Note: AMOVA: analysis of molecular variance; df: degrees of freedom; SS: sum of squares deviation; MS: mean squared deviation; Est. Var.: estimates of variance components; \%: percentage of total variance contributed by each component

Table 6. Genetic diversity of Indonesian seashore paspalum populations analyzed by microsatellite data

\begin{tabular}{lccccc}
\hline \multicolumn{1}{c}{ Population } & $\boldsymbol{P}(\boldsymbol{\%})$ & Ne & I & Ho & He \\
\hline Bali & 77.78 & 1.550 & 0.471 & 0.333 & 0.309 \\
Central Java & 88.89 & 1.757 & 0.573 & 0.503 & 0.383 \\
West Java & 66.67 & 1.511 & 0.448 & 0.611 & 0.319 \\
West Sumatra & 44.44 & 1.444 & 0.308 & 0.444 & 0.222 \\
Southeast Sulawesi & 22.22 & 1.133 & 0.125 & 0.111 & 0.083 \\
Riau & 55.56 & 1.333 & 0.385 & 0.556 & 0.278 \\
Mean & 59.26 & 1.455 & 0.385 & 0.426 & 0.266 \\
\hline
\end{tabular}

Note: $P(\%)$ : number (percentage) of polymorphic loci; Ne: mean effective number of alleles; I: Shannon's information index, He: mean expected heterozygosity; Ho: mean observed heterozygosity 


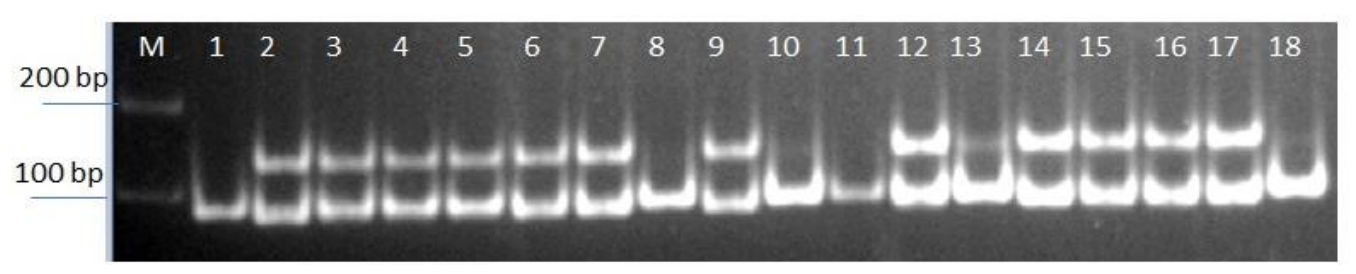

Figure 4. Electrophoregram of natural grass seashore paspalum germplasm using SSR marker ctg05574 in $2 \%$ agarose gel electrophoresis. Lane 1: 100 bp Ladder, Lane 2-19: seashore paspalum accessions. M= marker

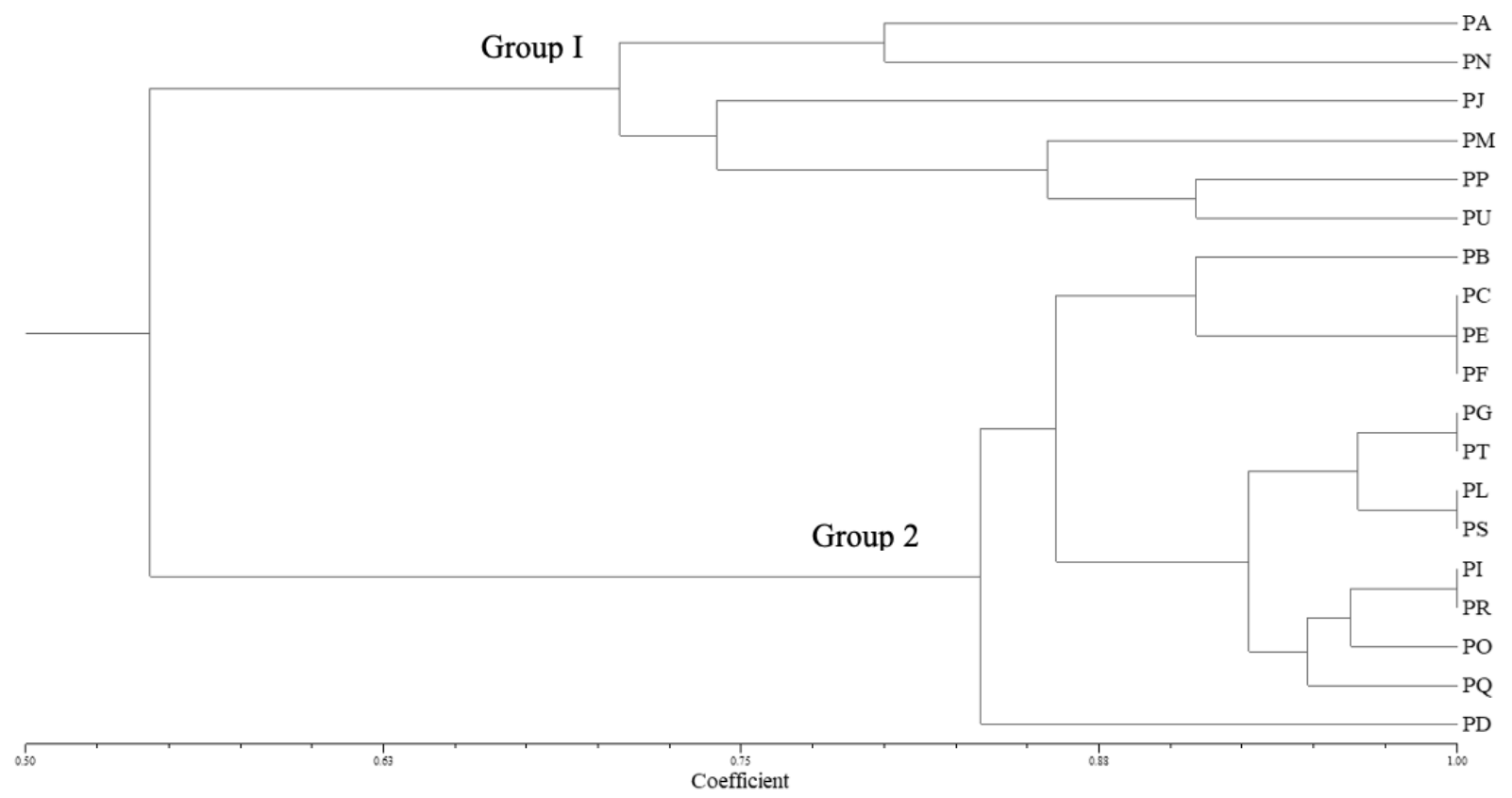

Figure 5. UPGMA dendrogram of seashore paspalum showing the genetic relationships between the 19 seashore paspalum accessions based on 9 microsatellite markers. Two major groups are labeled

\section{Discussion}

The genetic diversity analysis of Indonesian seashore paspalum collection showed that the PIC value in the present study $(0.13-0.61$; av $=0.32)$ was similar to PIC value of Shultz et al. (2013) $(0-0.78$; av=0.31) that reported 17 seashore paspalum cultivars from America with 75 microsatellite markers but higher than Shen et al. (2020) $(0.016-0.577 ; \mathrm{av}=0.24)$ that reported 58 seashore paspalum accessions and four cultivars from China with 19 microsatellite markers. The microsatellite primer of ctg02718 and ctg00695 in this study, were giving higher PIC values than Shultz et al. (2013). It indicates the ability of these two markers to distinguish between and within individuals themselves in a population. The higher the PIC value of microsatellite marker indicates that the microsatellite markers have high potential in identifying genetic relationships. The gene diversity parameter in this study $(0.14-0.66 ;$ av $=0.44)$ was higher than Shultz et al. (2013) $(0-0.80$; av=0.34). In this study, the microsatellite loci revealed that more alleles number and high gene diversity have a high PIC value or positively correlated with the number of alleles and gene diversity. The gene diversity was high in Central Java which indicates the presence of a large genetic diversity in Central Java collections as compared to those from other provinces. The within-population level genetic diversity of Indonesian seashore paspalum was obviously higher (83\%) compared to the among population level (12\%). It indicated that most variation in population genetics of Indonesian seashore paspalum occurs within populations.

Although the advancement of technology in genomics area, the Indonesian seashore paspalum collection remained uncharacterized at the molecular level such as in genetic diversity parameters. This has been one of limiting factors in their utilization for development of improved new turfgrass cultivars and conservation in Indonesia. The present study is the first major effort to characterize the Indonesian seashore paspalum collections at molecular level. This study shows that SSR technology is an effective and efficient method for genetic diversity analysis of Indonesian seashore paspalum.

During plantation, wide variation of natural grass accessions in turf density was clearly seen in experimental field (Figure 2). The highest variance was found in turfgrass quality, shoot density, and surface coverage. Thus, it can be used as parameter in further study of 
Paspalum diversity and breeding. In this study, 17 accessions were observed high in shoot density and turf quality within this $\mathrm{PH}$ from Ponorogo and PB from Kebumen were the highest in turf quality, shoot density, and surface coverage.

The cluster analysis of turf quality and morphological characterization separated three major groups. Group 1 characteristics were high in turf density, turf quality and surface coverage compare to other groups. The plant height was tall, the leaves were long and wide and long internode, producing many seeds with large spikelets, this group named as tall high-density ecotype. Gaetani et al. (2017) reported that varieties with high shoot density having the potential to wear resistance and damage recovery that are superior to others. It could replace some commercial variety and recognized as reference standards for the turfgrass industry. Brosnan and Deputy (2009) reported that wear resistance in seashore paspalum may be associated with some physiological and morphological traits and shoot density seems consistently associated with traffic tolerance. Group 2 characteristics were low in turf density, turf quality, and surface coverage. However, the plant height was relatively tall, the leaves were long and wide and long internode while the spikelet was short and less seed per spikelet, this group named as intermediate ecotype between Group 1 and Group 3. Group 3, contains Salam variety, characteristics were low in the turf density, turf quality, and surface coverage, and the plant height was relatively low, the leaf length was short and leaf width was narrow while the internode length and spikelet length was short and less seed per spikelet, this group named as dwarf low-density ecotype (Figure 3). On the contrary, within this group, Salam variety was actually high in shoot density. The dwarf low-density ecotype could be used as the potential recipient for high shoot density ecotype in the breeding purpose for grass golf courses.

The cluster analysis based on microsatellite markers separated into two groups. Group 1 clustered with widely used seashore paspalum "Salam" variety with the characteristic of leaf width was narrow and Group 2 with the characteristic of leaf width was wider. This result was consistent with the findings of Shultz et al. (2013) which were clustered into two major groups. Group I consisted of seashore paspalum accessions with fine to medium-fine leaves and Group II consisted of seashore paspalum accessions with coarse leaves and predominant stems. Grouping based on leaf texture in seashore paspalum had been observed previously (Liu et al. 1994).

The cluster analysis of turf quality and morphological characteristics compare with cluster analysis of molecular marker resulted in slightly similarity in grouping. Group 1 (narrow leaves) in molecular marker cluster consisted of Group 2 (intermediate) and Group 3 (dwarf low-density ecotype) in morphological cluster while Group 2 (wide leaves) in molecular marker cluster similar to Group 3 in morphological cluster (tall-high density ecotype). However, both clustering does not discriminate against the natural grass seashore paspalum accessions by their geographical origin. It could be due to the limitations of the sampling strategies such as the different habitats and environments were clustered together so that the material collected by the roadside might be a cultivar that has been widely used and accidentally collect similar material during sampling. García et al. (2007) and Liu et al. (2019) also reported that morphological markers do not discriminate individuals by their geographic origin. Certain accessions always have similar morphological characteristics when grown in the same environment; however, their genetic basis will not necessarily be the same. The accessions with a similar genetic basis clustered together based on the molecular markers; however, their morphological traits may be different because of the influence of the environment.

In conclusion, the genetic diversity of 23 Indonesian seashore paspalum assessed by microsatellite analysis detected narrow genetic diversity. The Contig02718 and Contig00695 markers have more alleles number, high gene diversity, and PIC value. The turf quality, shoot density, and surface coverage of PH (Ponorogo) and PB (Kebumen) accessions were high while PC (Tanah Lot) and PU (Jembrana) were similar to "Salam" variety in six morphological characters. The cluster analysis of morphological characterization separated three major groups. Group 1 was tall high-density ecotype. Group 2 was intermediate ecotype between Group I and Group 3. Group 3 was dwarf low-density ecotype. The cluster analysis of microsatellite markers divided into two groups. Group 1 clustered with "Salam" variety with narrow leaf width and Group 2 with wider leaf width and there was no geographical segregation of the natural grass seashore paspalum accessions. To enlarge the genetic base of seashore paspalum in Indonesia, the wide exploitation and identification of diverged genetic materials from the germplasm collection was required. It may contribute to plant breeders for the selection and develop new cultivars.

\section{ACKNOWLEDGEMENTS}

The author would like to gratefully acknowledge Mushlihatun Baroya for technical assistance and Randhy Ramadhan and Hatami for turfgrass experimental field maintenance. This work was financially supported by The Ministry of Research, Technology, and Higher Education year 2014-2015.

\section{REFERENCES}

Acuna CA, Martines EJ, Zilli AL, Brugnoli EA, Espinoza F, Marcon F, Urbani MH, Quarin CL. 2019. Reproductive systems in paspalum: Relevance for germplasm collection and conservation, breeding techniques, and adoption of released cultivars. Front Plant Sci 10: 1377. DOI: 10.3389/fpls.2019.01377.

Babu BK, Anjeli J, Sood S, Agrawal PK. 2017. Identification of microsatellites markers for finger millet genomics application through cross transferability of rice genome SSR markers. Indian J Genet Plant Breed 77 (1): 92-98.

Brosnan JT, Deputy J. 2008. Seashore Paspalum. Univ Hawaii Manoa, Coop Ext Serv TM-1. Turf Manag 1: 1-8.

Brosnan JT, Deputy J. 2009. Preliminary observations on the traffic tolerance of four seashore paspalum cultivars compared to hybrid bermudagrass. Horti Technol 19: 423-426. 
Chen ZB, Wang ML, Waltz C, Raymer PL. 2009. Genetic diversity of warm-season turfgrass: Seashore paspalum, bermudagrass, and zoysiagrass revealed by AFLPs. Floriculture Ornamental Biotech 3: 20-24.

Dellaporta SL, Wood J, Hicks JB. 1983. A plant DNA minipreparation: Version II. Plant Mol Biol Rep 1: 19-21.

Gaetani M, Volterrani M, Magni S, Caturegli L, Minelli A, Leto C, La Bella S, Tuttolomondo T, Virga G, Grossi N. 2017. Seashore paspalum in the Mediterranean transition zone: Phenotypic traits of twelve accessions during and after establishment. Ital J Agron 12 : 808. DOI: $10.4081 /$ ija.2017.808.

García MV, Balatti PA, Arturi MJ. 2007. Genetic variability in natural populations of Paspalum dilatatum Poir. analyzed by means of morphological traits and molecular markers. Genet Resour Crop Evol 54: 935-946. DOI: 10.1007/s10722-006-9147-8.

Hariprasanna K. 2017. Kodo Millet, Paspalum scrobiculatum L, in Millets and Sorghum. In: Patil JV (ed). Biology and Genetic Improvement. John Wiley \& Sons Ltd. Press, India. DOI: 10.1002/9781119130765.ch8.

Iskandar CD, Lubis TM. 2010. Determination of cadmium accumulation in livers and feces of Kacang goats grazing tsunami-affected land. J Agripet 10 (1): 7-12. DOI: 10.17969/agripet.v10i1.631.

Jalius, Muswita. 2013. Exploration of medicinal plants indigenous knowledge of Batin Ethnic Group, Jambi. Biospecies 6 (1): 28-37. [Indonesian]

Jia XP, Deng YM, Sun XB, Liang LJ, Ye XQ. 2015. Characterization of the global transcriptome using Illumina sequencing and novel microsatellite marker information in seashore paspalum. Genes Genom 37: 77-86. DOI: 10.1007/s13258-014-0231-8.

Stuart Jr G. 2015. Laua-laua. Philippine Medicinal Plant, Philippine.

Karmilasanti, Supartini. 2011. Diversity of medicinal plants and it's utilization at Tane' olen setulang village Malinau, East Kalimantan. Jurnal Penelitian Dipterokarpa 5 (1): 23-38. [Indonesian]

Li HY, Wang XS, Wang YP, Wu Y, Shen Q, Jia XP. 2016. Analysis of SSR information in EST resources and development of EST-SSR marker in Paspalum vaginatum. Chinese Agric Sci Bull 32: 96-102.
Liu ZW, Jarret RL, Duncan RR, Kresovich S. 1994. Genetic relationships and variation among ecotypes of seashore paspalum (Paspalum vaginatum) determined by random amplified polymorphic DNA markers. Genome 37: 1011-1017. DOI: 10.1139/g94-143.

Liu Y, Guo H, Wang Y, Shi J, Li D, Wang Z, Liu J. 2019. Measurement of genetic diversity of Chinese seashore paspalum resources through morphological and sequence-related amplified polymorphism analysis. J Am Soc Hortic Sci 144 (6): 379-386. DOI: 10.21273/JASHS04700-19.

Marsetyo M, Basri M, Basir-Cyio M. 2019. Response of Paspalum atratum to the level of urea fertilisation and mix plantation with legume herbs. J Agric Sci Technol 9: 114-119. DOI: 10.17265/21616256/2019.02.005.

NTEP (National Turfgrass Evaluation Program). 2008. National turfgrass evaluation program required protocols, standards, and applications for the visual field assessment of turfgrasses. Baltimore.

Pebriansyah A, Karti PDMH, Permana AT. 2014. Effect of drought stress and addition of arbuscular mycorrhizal fungi (amf) on growth and productivity of tropical grasses (Chloris gayana, Paspalum dilatatum, and Paspalum notatum). Pastura J Trop Forage Sci 2 (1): 41-48. DOI: 10.24843/Pastura.2012.v02.i01.p10.

Qi P, Eudy D, Schnable JC, Schmutz J, Raymer PL, Devos KM. 2019. High density genetic maps of seashore paspalum using genotypingby-sequencing and their relationship to the sorghum bicolor genome. Sci Rep 9: 12183. DOI: 10.1038/s41598-019-48257-3.

Rahayu, Zuamah H, Yang GM, Choi JS. 2014. Growth of zoysiagrass and seashore paspalum on volcano eruption and clayey soil with organic and inorganic fertilizers in Indonesia. Weed Turf Sci 3 (3): 240-245. DOI: 10.5660/WTS.2014.3.3.240

Shen Q, Bian H, Wei HY, Liao L, Luo XY, Ding XP, Raymer P. 2020. Genetic diversity of seashore paspalum revealed with simple sequence repeat markers. J Am Soc Horti Sci 145 (4): 228-235. DOI: 10.21273/JASHS04860-19.

Shultz KH, Raymer P, Scheffler BE, Arias RS. 2013. Development and characterization of seashore paspalum SSR markers. Crop Sci 53: 1-7. DOI: $10.2135 /$ cropsci2012.11.0671. 